\title{
GEOCHEMISTRY OF THE SERRA DO MAR GRANITOID MAGMATISM AND TECTONIC IMPLICATIONS, SOUTHERN BRAZIL
}

\section{PEDRO FRANCISCO TEIXEIRA KAUL ${ }^{1} \&$ UMBERTO GIUSEPPE CORDANI $^{2}$}

\begin{abstract}
The Neoproterozoic $(580 \pm 20 \mathrm{Ma})$ alkaline granitoid magmatism produced two rock associations in the Serra do Mar region, Southern Brazil. The first one $\left(70-76 \% \mathrm{SiO}_{2}\right)$ is metaluminous to weakly peraluminous, HFSE depleted relative to LILE, and includes the larger massifs mainly. The second one $\left(62-76 \% \mathrm{SiO}^{2}\right)$ comprises metaluminous as well as peralkaline rock-types and is enriched in HFSE relative to LILE. The granitoid massifs were emplaced within transtensional fault zones generated during the final stages of the agglutination process that led to the formation of the Gondwana supercontinent. As a whole, the Serra do Mar granitoid magmatism represents a transition from late orogenic calc-alkaline monzonitic to anorogenic alkaline (A-type) magmatism.
\end{abstract}

Keywords: geochemistry, granitoid magmatism, magmatic evolution, tectonic regime, Serra do Mar.

INTRODUCTION The granitoid magmatism of the Serra do Mar, Southern Brazil, generated within an elongated belt of about $250 \mathrm{~km}$, 30 to $50 \mathrm{~km}$ wide, 13 small granitoid batholiths and stocks, associated in space and time with volcanic-sedimentary sequences, isolated bodies of acid volcanic rocks, as well as acid dikes (Figs. 1 and 2).

In this paper the geochemistry of major and trace elements of the more representative rocks of such batholiths and stocks is described, with the aid of complete chemical analyses carried out in 65 samples. Moreover, the tectonic control of the emplacement of the granitoid massifs is characterized, taking into account paleostresses that have been probably active in the region at the end of Precambrian and beginning of Paleozoic times.

GEOTECTONIC SETTING The formation of the Gondwana supercontinent (Fig. 3) started at about 800-900 Ma ago, by means of the approximation and collision of several cratonic masses with different sizes (Brito Neves and Cordani 1991). The Luís Alves craton is one of such units, a microcontinent that after the mentioned process of agglutination resulted inserted between three other and larger continental masses: the Congo-São Francisco craton to the northnortheast, the Kalahari craton to the south-east, and the Paraná craton to the north-west, this latter entirely hidden beneath the Paraná basin sedimentary cover. In between such cratonic units, several collisional belts were developed, covering the time-span of the so-called Brasiliano orogenic cycle (about 800-500 Ma). They include the Ribeira, Paranaguá and Dom Feliciano belts in southern Brazil, very complex units which include accretionary prisms, magmatic arcs, marginal basins, tectonic slices, thrust belts and other tectonic units associated with collision.

The agglutination of Gondwana proceeded by successive continental collisions. In the case of the Luís Alves microcontinent, it proceeded from West to East, as revealed by the general ages of the magmatic arcs associated to it and indicated in figure 4: the Cunhaporanga (800-700 Ma), Três Córregos (700-600 Ma) and Paranaguá (600-550 Ma) magmatic arcs. As a consequence of the continental collisions, deformation was intense within the Luís Alves craton, with the production of new structures as well as the reactivation of older zones of weakness. One of these is the Piên transcurrent fault zone (PTFZ), a very large feature which marks the northwestern border of the craton, and its limit with the Ribeira belt. The other tectonic features, observed throughout the craton, are arranged in four different systems. Two of them represent shearing fault zones with N20-30E and N70-80E trends, and two others are related to small gravity fault systems, in many cases associated with acid dikes, with N50-60E and N20-30W trends.

The granitoid massifs are located over the Luís Alves craton and in part of the Ribeira belt. Their rocks are relatively homogeneous and usually devoid of deformation. Granitoid rock-types are ubiquitous, and make up the whole or the bulk of the massifs. Two rock associations (named in this work 1 and 2) are here characterized (Fig. 2). The first one includes pink to reddish, medium to coarse-grained subsolvus monzo, syeno and alkali-feldspar granites. Such varieties are found in the larger massifs and in some of the smaller ones. Association 2 includes hipersolvus, gray, medium-grained syenites, quartz-syenites and alkali-feldspar granites. Such varieties are related

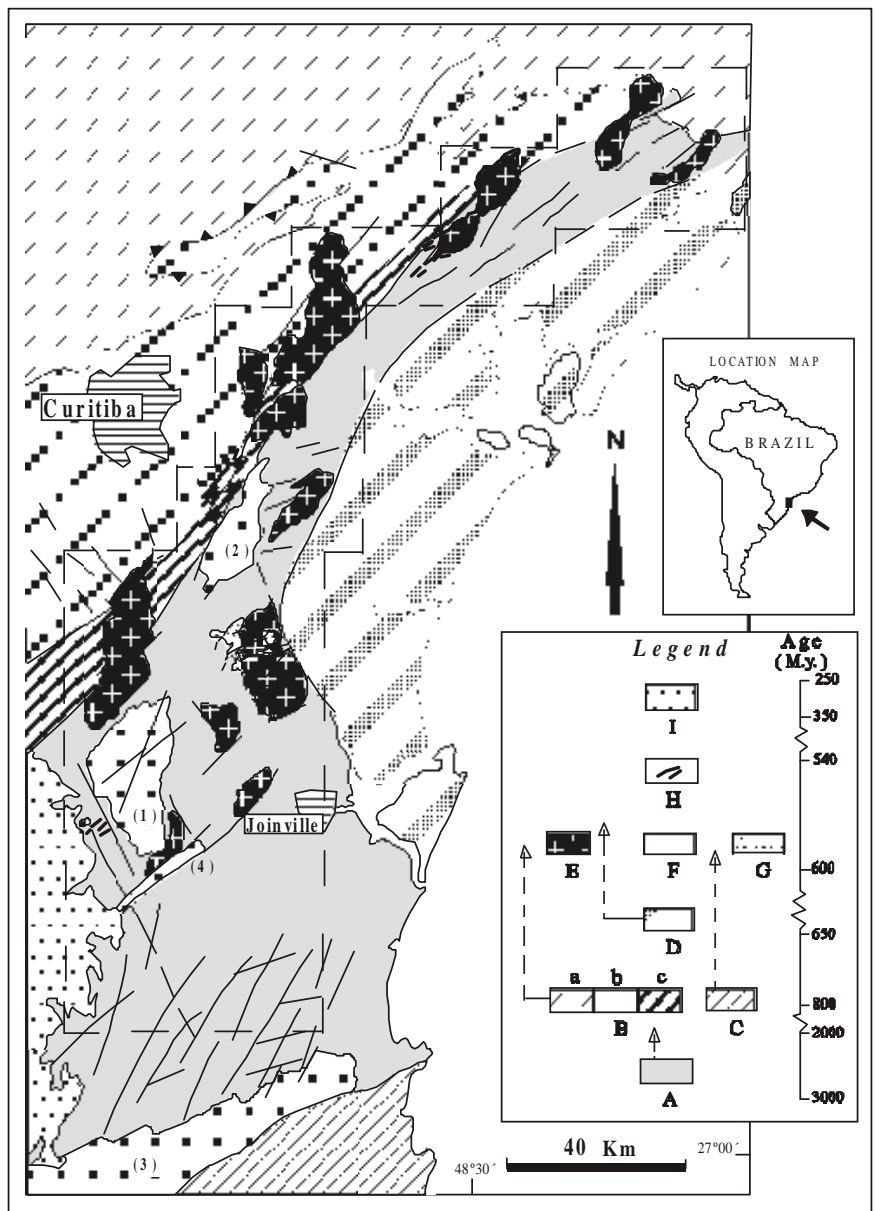

Figure 1 - Simplified geotectonic map of the Serra do Mar region and surroundings: A - Luiz Alves craton; $B$ - Ribeira belt ( $a$ - polydeformed metasedimentary rocks associated with granitoid intrusions related to the Cunhaporanga and Três Córregos magmatic-arcs; bneiss-migmatitic rocks of the rejuvenated basement, $c$-calk-alkaline deformed granitoids of the Piên transcurrent fault zone); $C$-Dom Feliciano belt; D - Paranaguá belt; EGranitoid massifs; $F$-volcanic-sedimentary sequences; $G$-Acid volcanic rocks; $H$-Acid dikes; 1 - Paleozoic sedimentary cover of the Paraná basin. The volcanic-sedimentary sequences fill the Campo Alegre (1), Guaratubinha (2) and Itajaí (3) basins, as well as the Corupá graben (4). Quaternary cover not represented.

to the smaller massifs mainly.

Volcanic-sedimentary sequences are important over the Luís Alves craton and cover areas up to $200 \mathrm{~km}^{2}$. They fill the Campo Alegre, Itajaí and Guaratubinha basins, as well as the Corupá graben. Some acid volcanic rocks occur in association with the northern part of the

1 - Fundação Instituto Brasileiro de Geografia e Estatística, Av. Rio Branco, 198, CEP 88015 - 200, Florianópolis, SC, Brazil. E-mail: kaul@ibge.gov.br

2 - Instituto de Geociências, Universidade de São Paulo, Rua do Lago, 562, Cidade Universitária, CEP 05508 - 900, São Paulo, SP, Brazil. E-mail: ucordani@usp.br 


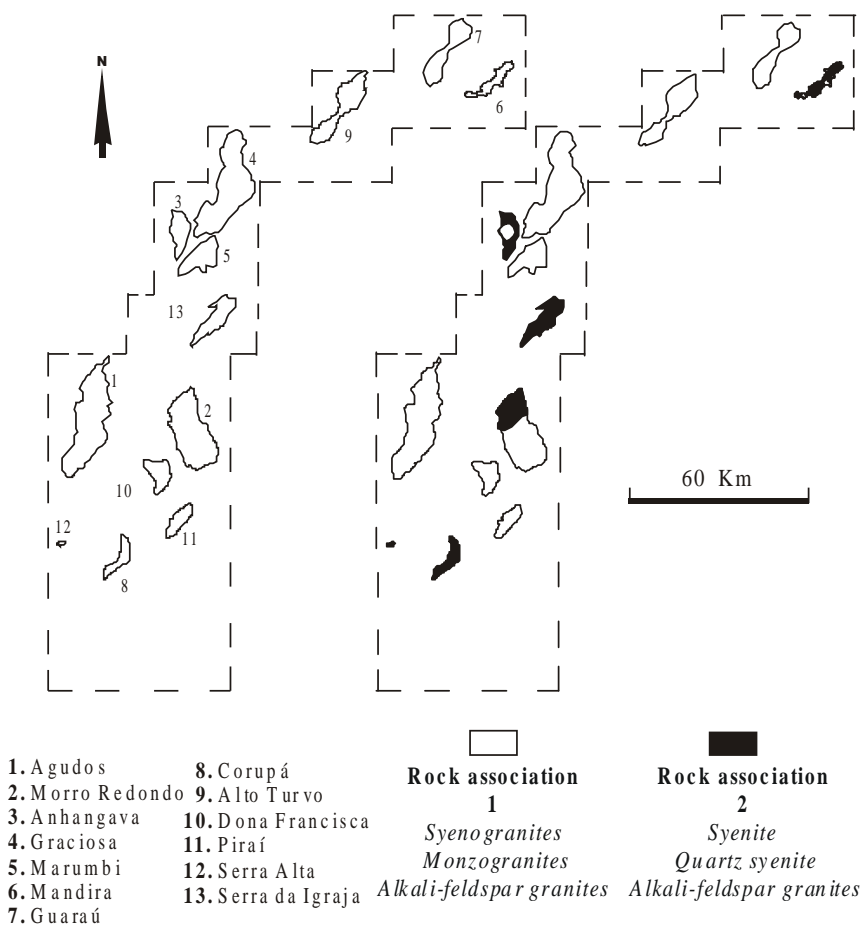

Figure 2 - The Serra do Mar granitoid massifs and their rock associations.

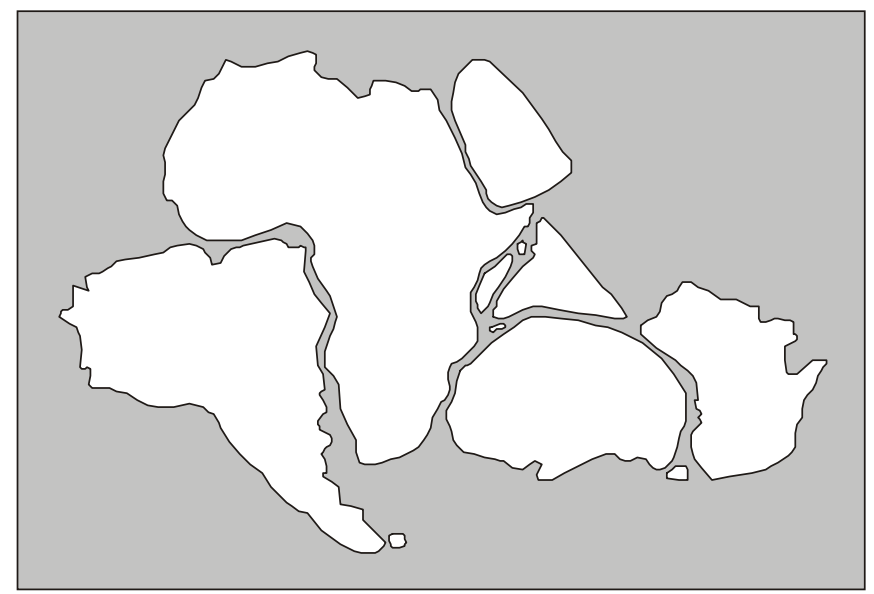

Figure 3 - Reconstruction of the gondwana supercontinent, modified from Kaul (1997).

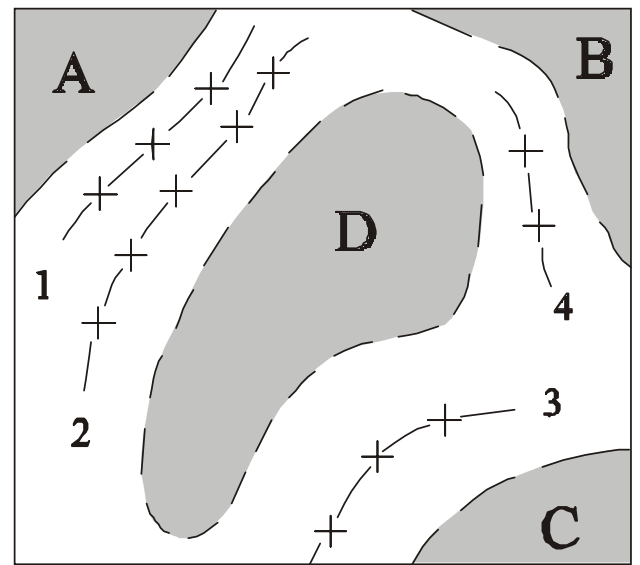

Figure 4 - Early stage of the Gondwana agglutination: the Luiz Alves craton (D) surrounded by the Cunhaporanga (1), Três Córregos (2), Pelotas (3) and Paranaguá magmatic arcs, as well as by the Paraná (A), congo-São Francisco $(B)$ and Kalahari $(C)$ cratons.
Morro Redondo massif. Acid dike swarms are frequent and cut through all the terranes of the Luís Alves craton, as well as part of those of the Ribeira belt.

GEOCHEMISTRY OF THE GRANITOID MASSIFS This paper is based on the doctoral work of one of the authors (Kaul 1997). The major elements, as well as $\mathrm{Zr}, \mathrm{Y}, \mathrm{Nb}, \mathrm{Rb}, \mathrm{Sr}$, and $\mathrm{Ba}$ were determined at the Institute of Geosciences of the University of São Paulo, while the REE elements were determined in several of the same rock samples at the Geosol laboratories in Belo Horizonte, MG. All rock samples were analyzed by induced coupled plasma.

The chemical analyses of the samples from rock associations 1 and 2 indicate in $\mathrm{Na}_{2} \mathrm{O}+\mathrm{K}_{2} \mathrm{O}$ vs. $\mathrm{SiO}_{2}$ diagram (Fig. 5) that both of them

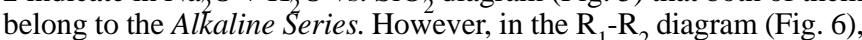
the samples occupy part of the field of the alkaline (anorogenic) magmatism and also part of the field of the monzonitic calc-alkaline (late-orogenic) magmatism. In the $\mathrm{A} / \mathrm{NK}$ vs. A/CNK diagram, the rocks of association 1 are metaluminous to weakly peraluminous, while those of association 2 are in part metaluminous and in part peralkaline.

Variation $(\Delta)$ and average $(\bar{x})$ of main geochemical indices for rocks of the Serra do Mar granitoid massifs are in Table 1. AI is the agpaitic index $\left[\mathrm{AI}=\left(\mathrm{Na}_{2} \mathrm{O}+\mathrm{K}_{2} \mathrm{O}\right) / \mathrm{Al}_{2} \mathrm{O}_{3}\right.$, mol. prop.]; $\mathrm{A} / \mathrm{CNK}$ is the alumina saturation index $\left[\mathrm{A} / \mathrm{CNK}=\mathrm{Al} \mathrm{O}_{3} /\left(\mathrm{CaO}+\mathrm{Na}_{2} \mathrm{O}+\mathrm{K}_{2} \mathrm{O}\right)\right.$, mol. prop.]; $\mathrm{F} / \mathrm{FM}$ is the mafic index $\left[\mathrm{F}^{2} \mathrm{FM}^{3}=\mathrm{FeO}_{\mathrm{t}} /\left(\mathrm{FeO}_{\mathrm{t}}+\mathrm{MgO}\right)\right.$, mol. prop.].

Harker's oxides vs. silica diagrams (Fig. 6) show that, while $\mathrm{SiO}_{2}$ increases, $\mathrm{Al}_{2} \mathrm{O}_{2}, \mathrm{CaO}, \mathrm{MgO}$ and $\mathrm{P}_{2} \mathrm{O}_{5}$ decrease for both associations.

- $\mathrm{Na}_{2} \mathrm{O}$ and $\mathrm{K}_{2} \mathrm{O}$ remain constant in association 1 , but decrease in association 2 , and $\mathrm{Fe}_{2} \mathrm{O}_{3}, \mathrm{MnO}$ and $\mathrm{TiO}_{2}$ decrease in association 1, but in the case of association 2 they decrease until $\mathrm{SiO}_{2}=74 \%$, but then they increase up to the end of the evolutionary trend.

Correlation between $\mathrm{CaO}$ and $\mathrm{Sr}$ can also be seen in figure 6, where rock association 1 produces a positive correlation, while rock association 2 indicates a variation in $\mathrm{CaO}$ content while keeping a fairly constant but very low $\mathrm{Sr}$ content.

The diagrams of figure 6 clearly characterize rock associations 1 and 2 , which are probably related to at least two different magma sources for the granitoid rocks of the Serra do Mar. As an alternative possibility, the different magmas could result from different degrees of crustal assimilation by mantle derived liquids, as suggested by Kaul (1997).

Correlation between $\mathrm{Rb}$ and $\mathrm{Sr}, \mathrm{Ba}$ and $\mathrm{Sr}$, and $\mathrm{Y}$ and $\mathrm{Yb}$ can be seen in diagrams of figure 7. $\mathrm{Rb}$ and $\mathrm{Sr}$ show negative correlation in both rock associations. Moreover, for the same values of $\mathrm{Sr}$, higher values of $\mathrm{Rb}$ are found in the rocks of association 1. Ba vs. Sr diagram shows three different trends. One of them $(\mathrm{Ba} / \mathrm{Sr}=5.5)$ corresponds to rock association 1, with samples from the Agudos, Graciosa, and Marumbi massifs, plus the metaluminous nucleus of the Anhangava massif. The second trend $(\mathrm{Ba} / \mathrm{Sr}=11)$ is also related to rock association 1, but with samples from the Piraí, Dona Francisca massifs and the metaluminous part of the Morro Redondo massif. This separation of the rocks of association 1 into two different trends seems to reflect a greater geochemical affinity and a possible closer genetic link among the members of each trend. The other trend $(\mathrm{Ba} / \mathrm{Sr}=20)$ is related to the rock samples of rock association 2 .

In $\mathrm{Y}$ vs. $\mathrm{Yb}$ diagram, linear trends can be observed for rock associations 1 and 2, all them passing through the origin of the diagram, and corresponding to $\mathrm{Y} / \mathrm{Yb}$ values between 10 and 20 .

In the variation diagrams of Pearce et al. (1984), figure 8, the plots of the Serra do Mar granitoids fall almost entirely in the field of the granitic rocks formed in intra-plate tectonic environments. The $\mathrm{Nb} / \mathrm{Y}$ ratio exhibits average values of 0.76 and 0.67 , respectively, for rock associations 1 and 2 .

Figure 9 shows the ranges of condrite normalised REE patterns for the rocks of associations 1 and 2 , where it can be seen that the degree of enrichment relative to chondrite is larger for association 2. LREE fractionation, measured by the $\mathrm{Ce}_{N} / \mathrm{Sm}$ ratio, is generally fairly high, while HREE fractionation, measured by the $\mathrm{Gd} / \mathrm{Yb}$ ratio is usually low. For LREE, in the average, the association $2 \mathrm{is}$ enriched by a factor 1.35 in relation to the association 1, while for the HREE the factor of enrichment is close to 2.0. The Eu negative anomalies vary from weak to strong for the rocks of both associations $\left(\mathrm{Eu} / \mathrm{Eu}^{*}=0.23\right.$ in the average for association 1 and $\mathrm{Eu} / \mathrm{Eu}^{*}=0.21$ in the average for association 2). 
Table 1 - Variation and average of geochemical indices for rocks of the Serra do Mar granitoid massifs.

\begin{tabular}{|c|c|c|c|c|c|c|c|}
\cline { 3 - 7 } \multicolumn{2}{c|}{} & \multicolumn{3}{c|}{ Rock association 1 } & \multicolumn{3}{c|}{ Rock association 2 } \\
\cline { 3 - 8 } \multicolumn{2}{c|}{} & $\begin{array}{c}\text { Monzo- } \\
\text { granite }\end{array}$ & $\begin{array}{c}\text { Syeno- } \\
\text { Granite }\end{array}$ & $\begin{array}{c}\text { Alkali-feldspar } \\
\text { granite }\end{array}$ & Syenite & $\begin{array}{c}\text { Quartz- } \\
\text { syenite }\end{array}$ & $\begin{array}{c}\text { Alkali-feldspar } \\
\text { granite }\end{array}$ \\
\hline $\begin{array}{c}\mathrm{SiO}_{2} \\
(\%)\end{array}$ & $\Delta$ & $71.51-73.67$ & $70.55-76.49$ & $70.35-76.34$ & $62.68-65.27$ & $67.39-68.72$ & $69.19-76.39$ \\
\hline & $\overline{\mathrm{X}}$ & 72.89 & 74.72 & 74.20 & 63.54 & 68.05 & 74.58 \\
\hline $\begin{array}{c}\mathrm{Na}_{2} \mathrm{O}+\mathrm{K}_{2} \mathrm{O} \\
(\%)\end{array}$ & $\Delta$ & $8.05-8.64$ & $8.05-10.24$ & $8.59-10.24$ & $10.92-11.32$ & $10.36-10.93$ & $8.30-10.20$ \\
\hline & $\overline{\mathrm{X}}$ & 8.39 & 8.76 & 9.00 & 11.10 & 10.64 & 9.03 \\
\hline $\mathrm{K}_{2} \mathrm{O} / \mathrm{Na}_{2} \mathrm{O}$ & $\Delta$ & $1.20-1.39$ & $1.00-1.62$ & $1.02-1.62$ & $1.01-1.11$ & $0.99-1.11$ & $0.63-1.19$ \\
\hline & $\overline{\mathrm{X}}$ & 1.26 & 1.31 & 1.29 & 1.05 & 1.05 & 1.01 \\
\hline $\mathrm{AI}$ & $\Delta$ & $0.58-0.85$ & $0.58-1.02$ & $0.88-1.02$ & $0.91-0.96$ & $0.97-1.01$ & $0.95-1.13$ \\
\hline & $\overline{\mathrm{X}}$ & 0.69 & 0.87 & 0.93 & 0.94 & 0.99 & 1.04 \\
\hline $\mathrm{A} / \mathrm{CNK}$ & $\Delta$ & $1.00-1.02$ & $0.94-1.08$ & $0.94-1.06$ & $0.86-0.88$ & $0.89-0.90$ & $0.85-0.97$ \\
\hline & $\overline{\mathrm{X}}$ & 1.01 & 1.00 & 0.99 & 0.87 & 0.89 & 0.91 \\
\hline $\mathrm{F} / \mathrm{FM}$ & $\Delta$ & $0.69-0.83$ & $0.69-1.00$ & $0.80-0.99$ & $0.85-0.94$ & $0.94-0.99$ & $0.94-1.00$ \\
\hline & $\mathrm{X}$ & 0.75 & 0.85 & 0.90 & 0.89 & 0.96 & 0.98 \\
\hline
\end{tabular}
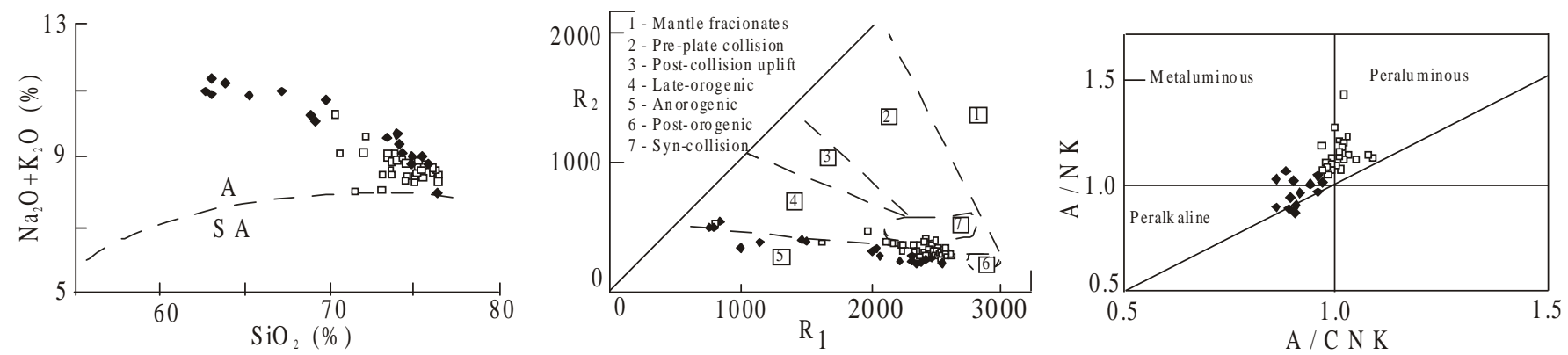

Figure $5-\left(\mathrm{Na}_{2} \mathrm{O}+\mathrm{K}_{2} \mathrm{O}\right)$ vs. $\mathrm{SiO}_{2}, \mathrm{R}_{1}$ vs. $\mathrm{R}_{2}$ and $\mathrm{A} / \mathrm{NK}$ vs. A/CNK diagrams for the Serra do Mar rock associations 1 (open squares) and 2 (filled diamonds). Dashed line in the first diagram is the boundary of alkaline (A) and sub-alkaline (AS) fields, after Miyashiro (1978)

REE behavior in the magmatic evolution of the massifs is illustrated by some diagrams (Fig. 10) relative to the Agudos massif (representing rock association 1) and the Corupá massif (representing rock association 2). We consider that each of these REE patterns represent one particular magmatic liquid. In the case of the Agudos massif, evolution occurred between 71 and $76 \% \mathrm{SiO}_{2}$, and in the Corupá massif between 63 and 75\%. From the figure, it can be seen that in the two massifs, REE behavior is quite similar. Only minor differences are noted in the shapes of the REE spectra, as a consequence of the different mineral phases that govern magmatic evolution. HREE contents increase with differentiation. However, the LREE increase until almost the end of the evolution, when they then exhibit a clear decrease. This may be explained by the fractionation of an accessory mineral rich in LREE, such as allanite, a mineral that is effectively present in smaller proportions in the more differentiated rock varieties. However, Vlach (1999) verified the presence of Cechevkinite, a LREE bearing accessory mineral, in the quartz syenites of the Corupá massif, belonging to association 2. The presence of such mineral phase may explain the high contents of LREE, as well as the highly fractionated REE patterns in the relatively more mafic rocks of association 2 .

In all cases, Eu content decreases continuously from the beginning to the end of the magmatic evolution, resulting in progressively more pronounced $\mathrm{Eu}$ anomalies. The final REE patterns $\left(\mathrm{SiO}_{2} @ 75-76 \%\right)$ are almost flat, with $\mathrm{Ce}_{N} / \mathrm{Yb}_{\mathrm{N}}$ near 1.0 and with a strong negative Eu anomaly. An alternative explanation for the strong Eu depletion in the more felsic rock types could be by hydrothermal alteration occurring associated to low temperature subsolidus recrystallization, as described by Bowden et al. (1979).

The model of magmatic evolution by fractional crystallization in the two rock associations is consistent with the geochemical data here presented, good indications being for instance the quasi-linear correlation in the $\mathrm{Ba}$ vs. Sr and $\mathrm{Y}$ vs. Yb diagrams, as well as the general behavior of the REE. The behavior of the major element oxides indicate a differentiation process controlled mainly by feldspars, also confirmed by the negative Eu anomalies which increase toward the end of the magmatic evolutions. In addition, at least in the case of the Agudos massif (Fig. 10), the REE pattern seems to indicate the importance of the crystallization of amphibole, producing the smooth concavity in the HREE portion of the REE spectra.

TECTONIC CONTEXT OF THE GRANITOID MAGMATISM

Based on the distribution of the tectonic elements and of the igneous masses of the Serra do Mar (Fig. 1), it is possible to interpret the tectonic evolution of the area, at the end of Neoproterozoic times, by the succession of at least three tectonic regimes (see Kaul 1997), two of which allowing the ascension, through the continental lithosphere, of granitoid magmas (Fig. 11).

The first of them is a compressive tectonic regime (Fig. 11A), related to the continental collision of the Luís Alves and Paraná cratons, producing thrust faults and nappes with general N40E trends and tectonic vergence toward the northwest. It was followed by a transtensive tectonic regime (Fig. 11B) associated to transcurrent sinistral fault movements, that transformed the previous thrust faults and developed the Piên transcurrent fault zone (PTFZ). Gravity faults N20-30W were also developed, and these were the sites of ascension for the larger massifs (Agudos, Morro Redondo, Graciosa/Marumbi) as well as the smaller bodies of Piraí and Dona Francisca. The volcanic-sedimentary basin of Campo Alegre (1) was also formed at this time, interpreted as the main period of formation of granitoids, at 

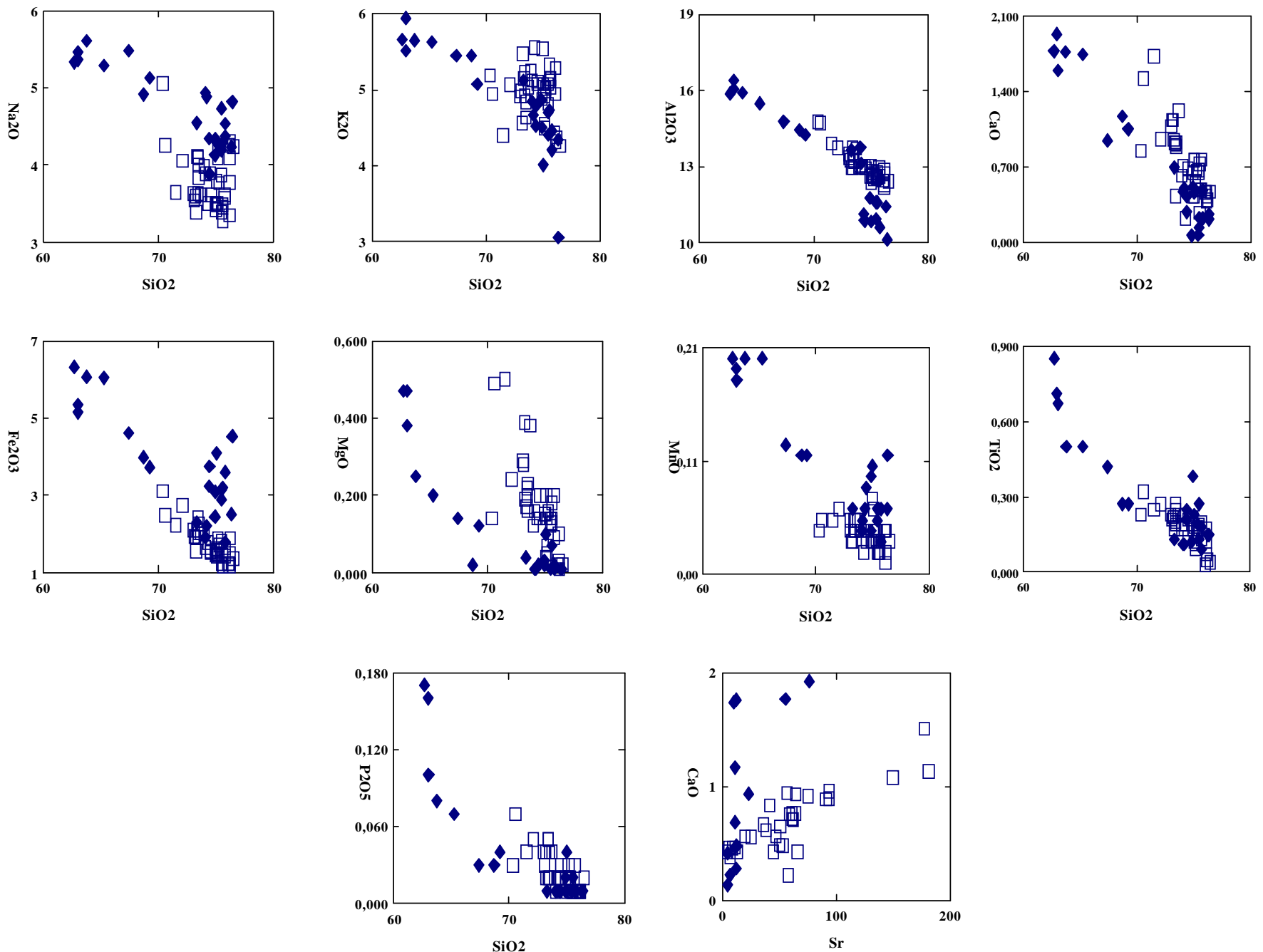

Figure 6 - Harker's oxydes vs. silica and CaO vs. Sr diagrams for the Serra do Mar rock associations. Symbols as in Figure 5.
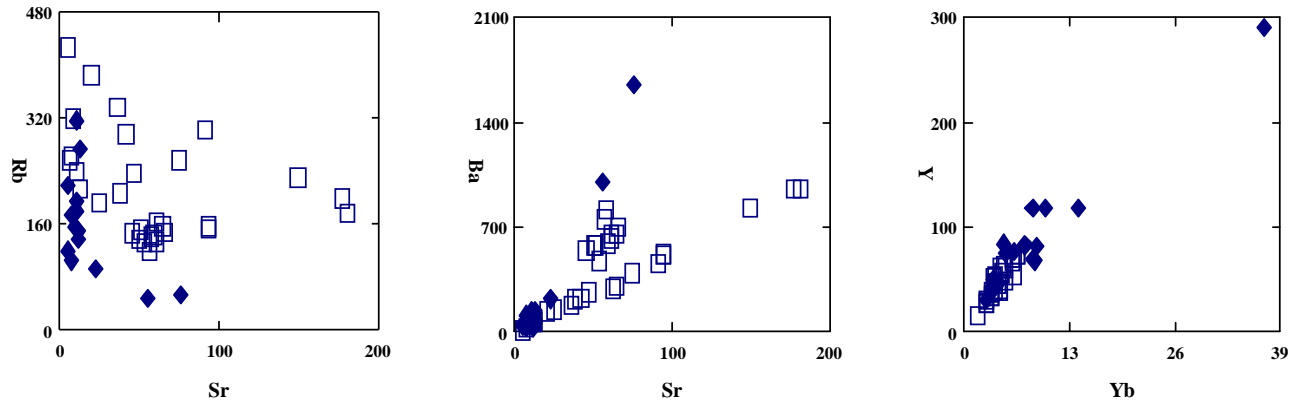

Figure 7 - Rb vs. Sr, Ba vs Sr and Y vs. Yb diagrams for the Serra do Mar rock associations. Symbols as in Figure 5.
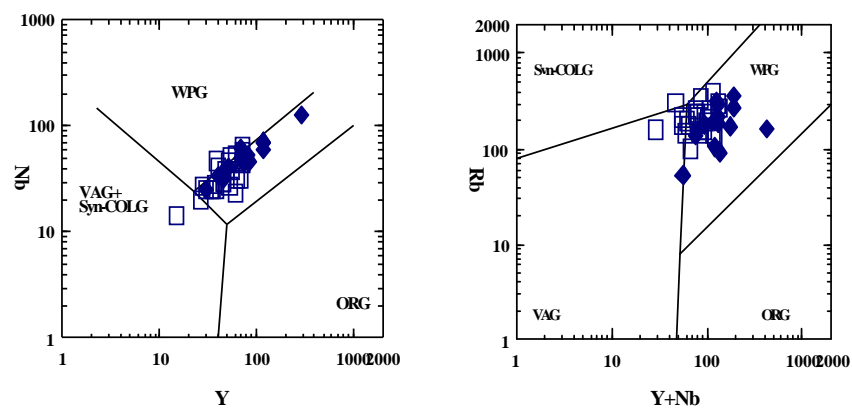

Figure 8 - Nb vs. $Y$ and $R b$ vs. $(\mathrm{Nb}+\mathrm{Y})$ diagrams for the Serra do Mar rock associations. Symbols as in Figure 5. 


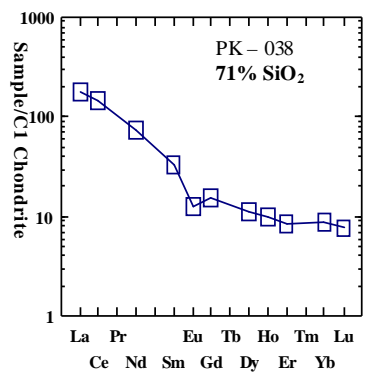

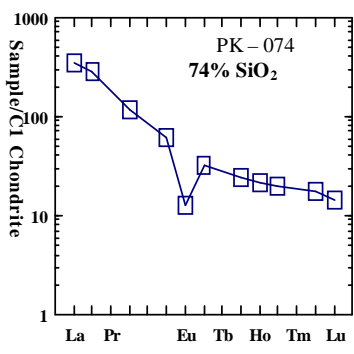

Ce Nd Sm Gd Dy Er Yb

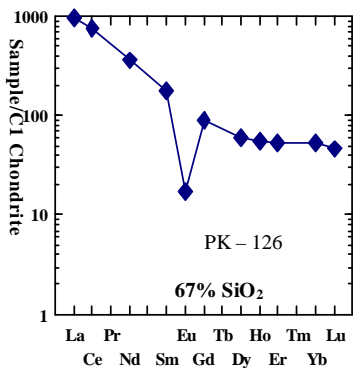

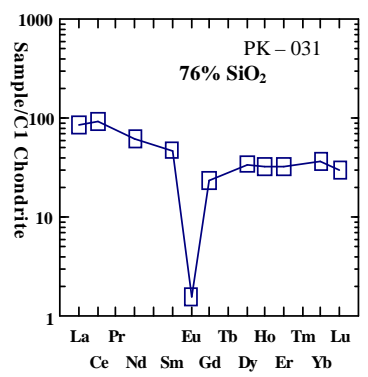
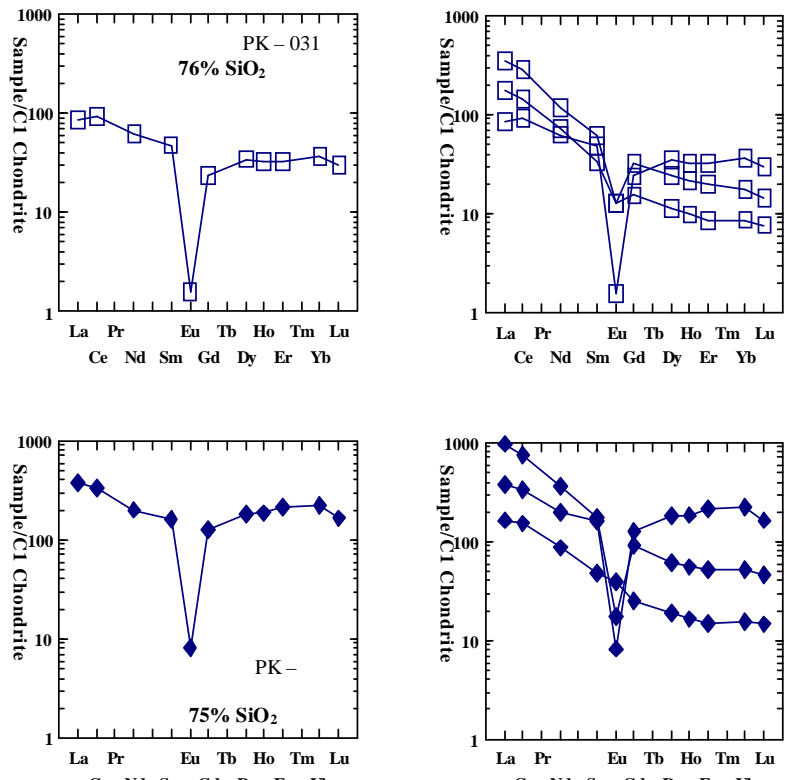

Figura 10 - Sequence of chondrite-normalized REE patterns for rock-samples from the Agudos (upper diagrams) and Corupá (lower diagrams) massifs, representing magmatic evolutions of rock associations 1 and 2 respectivelly. Simbols as in figure 5.

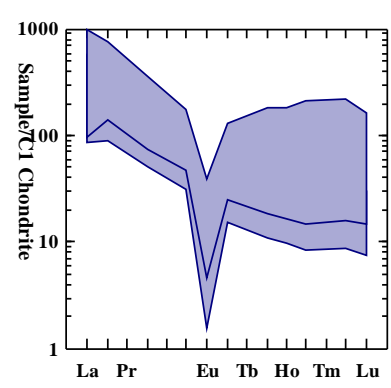

Ce Nd Sm Gd Dy Er Yb

Figure 9 - Range of condrite-normalised REE patterns for the Serra do Mar rock associations 1 (25 samples; area covered by horizontal lines) and 2 (14 samples; area covered by vertical lines).

about $580 \mathrm{Ma}$. The third tectonic regime, also transtensive in character, was related to the continental collision between the Luís Alves (+ Paraná) craton and the Congo-São Francisco craton. It reactivated tectonically the Piên transcurrent fault zone, this time with a dextral movement (Fig. 11C), producing a fracturing in the Agudos and Graciosa/Marumbi massifs. Gravity faults N30-60E were developed, to which the Guaratubinha (2) and Corupá (3) volcanic-sedimentary basins are related. The same fault systems were also used for the ascension of several magmatic rocks, making up some of the smaller massifs, as well as some intrusive bodies within the larger ones. Acid dike swarms were also formed in association with the N50-60E fault zones. These successive reactivations occurred between 580 and 540 Ma., and the observed hydrothermalism that affected the entire region is related to them.

As a whole, the Serra do Mar granitoid magmatism as shown in figure 5 represents a transition from calc-alkaline monzonitic (lateorogenic) to alkaline (anorogenic, A-type) magmatism.

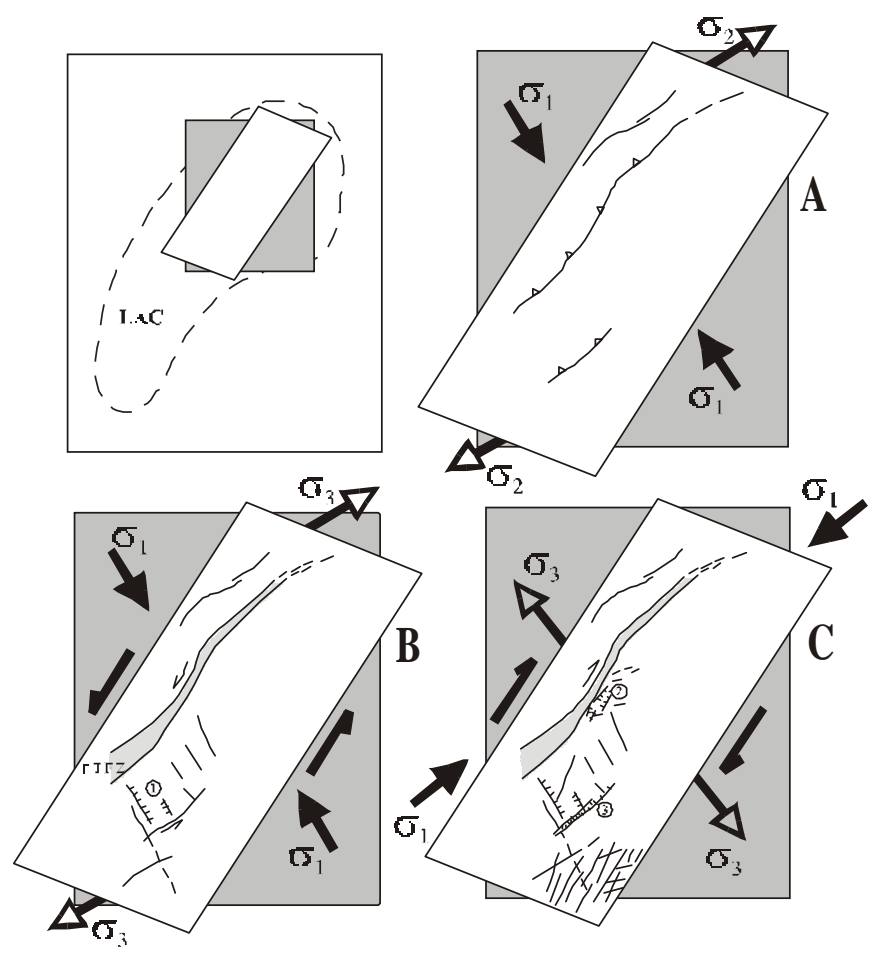

Figure 11 - Schematic representation of the tectonic conditions that probably occurred in the Luiz Alves craton between the end of Precambrian and beginning of Paleozoic times. Compressive tectonic regime (A) was probably followed by transtensive regimes associated first to transcurrent sinistral movements $(B)$ and finally to transcurrent dextral movements.

\section{References}

Brito Neves B.B. \& Cordani U.G. 1991. Tectonic evolution of South America during the Late Proterozoic. Precambrian Research 53:29-40.

Bowden P., Bennett J.N., Whitley J.E., Moye A.B. 1979. Rare earths in nigerian mesozoic granites and related rocks. Phys. Chem. Earth, 11:479-491.

Kaul P.F.T. 1997. O magmatismo na Serra do Mar e adjacências (Sul do Brasil) no final do Neoproterozóico e seus condicionantes tectônicos. Inst. de Geociências, Universidade de São Paulo, São Paulo, PhD thesis, 293 p..

Miyashiro A. 1978. Nature of alkalic volcanic rock series. Contributions to Mineralogy and Petrology, 66:91- 104.

Pearce J.A., Harris N.B.W., Tindle A.G. 1984. Trace element discrimination diagrams for the tectonic interpretation of granitic rocks. Journal of Petrology, London, 25:956983.
Vlach S.R.F. 1999. Ocorrência e variações composicionais de Chevkinita-Ce e Allanita ($\mathrm{Fe}$ ) em quartzo-sienitos do maciço Corupá (SC), província Serra do Mar. In: Congresso de Geoquímica dos Países de Língua Portuguesa, V, e Congresso Brasileiro de Geoquímica, VII, Porto Seguro, Anais, 627-630.

Contribution IGC-135

Received March 1, 2000 Accepted for publication May 10, 2000 